\title{
Notes on the vocalizations of Chinese Babax (Babax lanceolatus)
}

Peter Boesman

In the following we briefly analyze and compare voice of the different races of Chinese Babax (Babax lanceolatus). We also try to quantify the extent of any vocal differences using the criteria proposed by Tobias et al. (2010), as a support for taxonomic review.

We have made use of sound recordings available on-line from Xeno Canto (XC).

Song of race woodi is said to be different (Collar et al. 2016, Rasmussen et al. 2012). A comparison of sonograms:

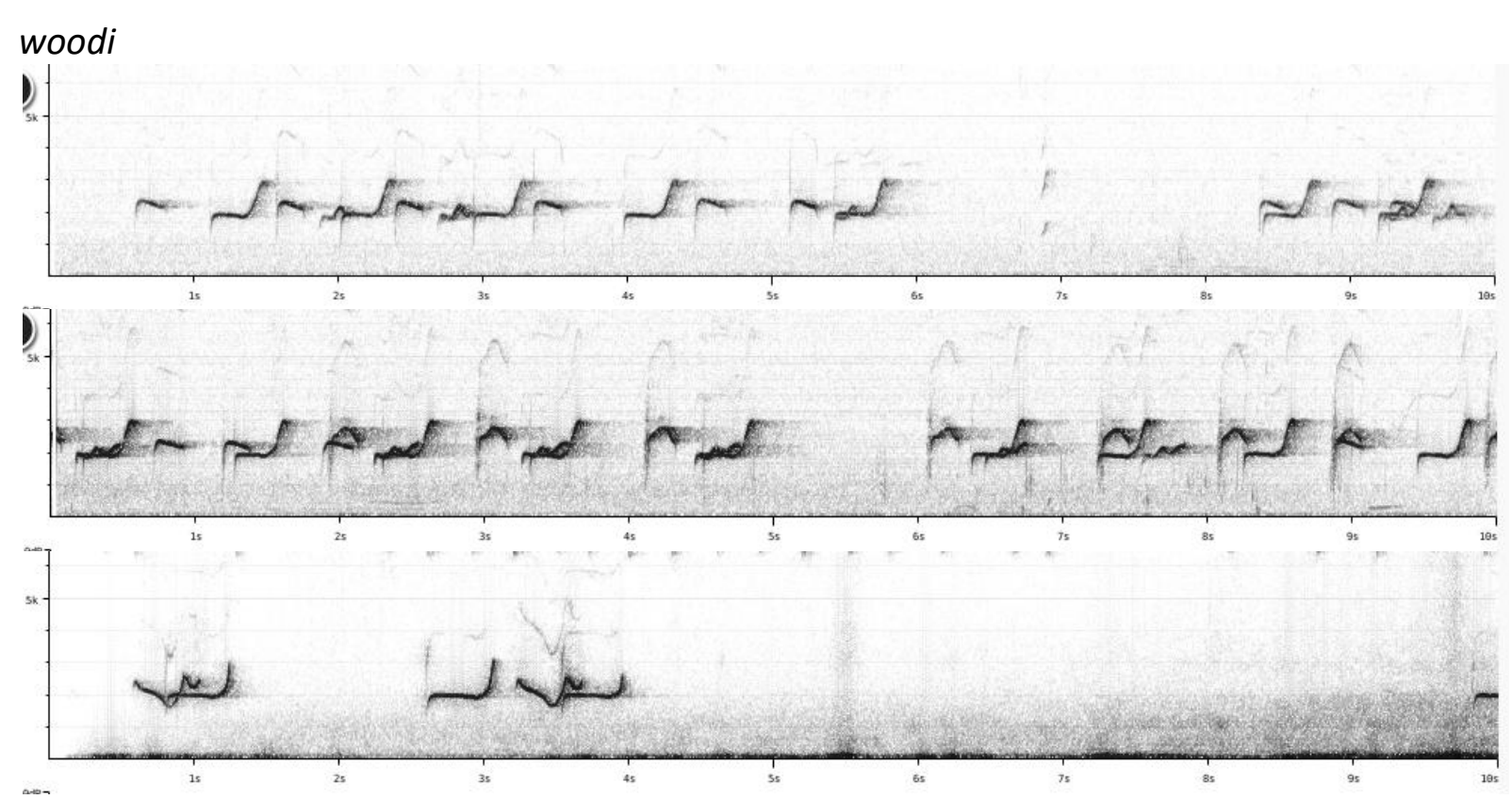

Other races (only nominate?)

NC China

C China
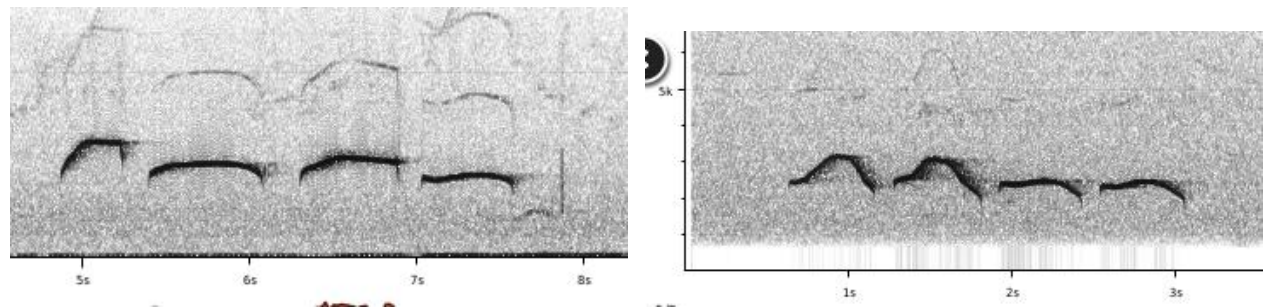

Some further sonograms can be found in Ripley's guide (Rasmussen et al. 2012).

Based on the few available recordings, it would seem that voice of woodi is indeed quite different from nominate: woodi seems to sing mainly in asynchronuous duet (or in group) with notes often overlapping in time, and note shapes (and duration) are quite different from nominate. Nominate seems to sing mainly phrases of 4-5 whistles at a rather flat pitch (hard to verify this is of a single bird or not, but if in duet then synchronuous without any overlap between song of both birds). 

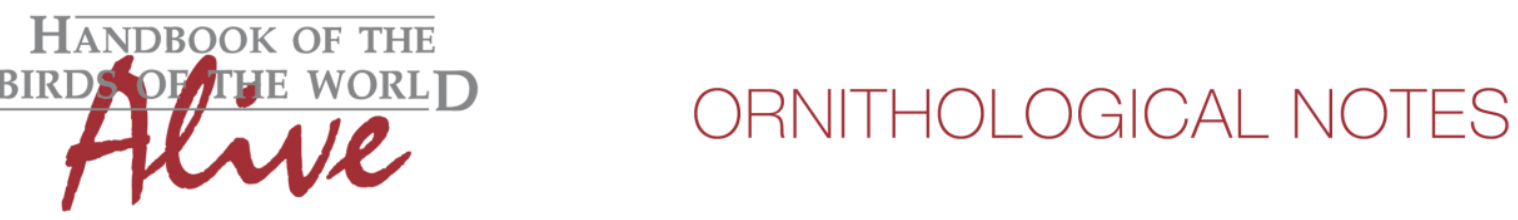

More recordings would be needed to increase confidence about the above-mentioned differences, but tentatively one could score e.g. based on 'typical number of notes/phrase' and 'note shape' or 'note duration', leading to an estimated vocal score of about $2+1=3$.

This note was finalized on 13th April 2016, using sound recordings available on-line at that moment. We would like to thank in particular the sound recordists who placed their recordings for this species on XC: Nick Athanas, Brian Cox, Frank Lambert, Mike Nelson and Yong Ding Li.

\section{References}

Collar, N. \& Robson, C. (2016). Chinese Babax (Babax lanceolatus). In: del Hoyo, J., Elliott, A., Sargatal, J., Christie, D.A. \& de Juana, E. (eds.). Handbook of the Birds of the World Alive. Lynx Edicions, Barcelona. (retrieved from http://www.hbw.com/node/59609 on 13 April 2016).

Rasmussen, P.C, Anderton, J.C. Birds of South Asia. The Ripley Guide. Lynx Edicions, Barcelona.

Tobias, J.A., Seddon, N., Spottiswoode, C.N., Pilgrim, J.D., Fishpool, L.D.C. \& Collar, N.J. (2010). Quantitative criteria for species delimitation. Ibis 152(4): 724-746.

\section{Recommended citation}

Boesman, P. (2016). Notes on the vocalizations of Chinese Babax (Babax lanceolatus). HBW Alive Ornithological Note 275. In: Handbook of the Birds of the World Alive. Lynx Edicions, Barcelona. (retrieved from http://www.hbw.com/node/1251716 on 6 October 2016). 